\title{
Corporate Borrowing and Growth Option Value: The Limited Liability Effect
}

\author{
Jyh-Bang Jou*
}

\begin{abstract}
A firm issues bonds before undertaking a risky continuous investment project that is costly to later either expand or contract. The firm's existing debt load causes it to install a smaller capacity because equity has limited liability. This lowers debt value, but such a cost should be borne by equityholders because debtholders will rationally anticipate equityholders' future behavior. The firm's choice of debt levels balances this agency cost against the tax shield benefit. As the firm incurs higher costs to later expand capacity, its growth option value becomes lower. The simulation results of this article are in line with Myers' conjecture (1977), which states that a firm's debt capacity is inversely related to its growth option value. (JEL G32)
\end{abstract}

\section{Introduction}

Myers (1977) considers a firm that exercises the investment option after debt is in place but before debt matures. Myers assumes that the firm is concerned solely with its equityholders upon investing. This leads to a conflict of interest between equity and debt holders because equity has limited liability. Myers then reaches two conjectures. First, the firm will be more likely to pass up profitable investment projects as the firm issues more bonds, i.e., the "debt overhang" problem will arise. Second, as the firm has more growth opportunities, it will bear a larger agency cost associated with the "debt overhang" problem, and therefore, will issue fewer bonds. Myers, however, does not endogenize capital structure decision to validate his second conjecture.

To investigate the Myers second conjecture, a large volume of empirical articles use such parameters as R\&D intensity and the ratio of a firm's market value to its book value to proxy growth option values (see, e.g., Bradley, Jarrell, and Kim 1984; Titman and Wessels 1988; and Smith and Watts 1992). ${ }^{1}$ These proxies, however, are overlooked by the theoretical literature on

\footnotetext{
* Jyh-Bang Jou, Graduate Institute of National Development, College of Social Science, National Taiwan University, Taipei, Taiwan 106, jbjou@ccms.ntu.edu.tw. I would like to thank the editor (J. Zietz), two anonymous reviewers, Chaujung Kuo, Tan Lee, Jerry Wang, and seminar participants at the 9th Conference on the theories and practices of security and financial markets held at the National Sun Yat-Sen University in December 2000. Financial support under Grant NSC88-2416-H-002-013 from the National Science Council, Executive Yuan, R.O.C., is gratefully acknowledged.

${ }^{1}$ Gaver and Gaver (1993) provide another four proxies, which include (1) the ratio of market to book value of equity, (2) the earnings/price ratio, (3) the variance of the total stock return of the firm, and (4) the frequency that a firm is included in the holdings of growth-oriented mutual funds.
} 
optimal financial structure. This article will also abstract from these proxies, but will use the proxy provided by Abel, Dixit, Eberly, and Pindyck (1996), who focus on an all-equity financed firm. Abel et al. consider how the limitations on the firm's ability to later expand or contract capacity affect its initial capacity decision. They also show that the firm's growth option value will be lower as the firm purchases capital at a higher price in the later period. By introducing both taxation and debt financing into their model, this article is able to investigate the Myers second conjecture.

This article builds a two-period model. In period 1, a firm issues bonds, followed by installing an initial capacity. After issuing bonds, the firm is acting in the interest of its equityholders. Uncertainty arises at the beginning of period 2. The purchase price of capital in period 2 is higher than its period 1 price, making expansion costly. ${ }^{2}$ The resale price of capital in period 2 is lower than its period 1 price, making contraction costly. ${ }^{3}$ After the state of nature in period 2 is realized, the firm is obliged to pay the debtors off. If this state of nature is good enough, the firm will decide whether to expand, maintain, or contract capacity and will then pay the debtors off; otherwise, the firm will go bankrupt. After bankruptcy, debtholders will control the firm and then decide a new level of capacity. Debt payments are assumed to be tax deductible with full loss offsets, ${ }^{4}$ and the costs associated with bankruptcy are ignored. ${ }^{5}$

The firm's existing debt load causes it to install a smaller capacity in period 1, thus yielding an agency cost resembling that investigated by Myers (1977). The firm's choice of debt levels balances this agency cost against the tax advantage of debt. This article then finds that if a rise in the purchase price of capital in period 2 (i.e., a lower growth option) mitigates the debt overhang problem, then debt capacity is likely to be expanded. This special case is thus in line with the Myers second conjecture. This article also finds that if a rise in the resale price of capital in period 2 exacerbates the debt overhang problem, then debt capacity is likely to be contracted.

This article is closely related to several recent articles that investigate the issue of optimal capital structure. Jou (2001) considers a firm that is unleveraged and holds an option to make an irreversible investment project. Subsequently, the firm simultaneously chooses the price at which the project is exercised and the amount of bonds to be issued. Jou assumes that the exercise cost may rise over time and discusses how this (i.e., a lower growth option value) affects the choice of debt levels. Jou, however, ignores the agency cost associated with the "debt overhang" problem. On the other hand, similar to this article, several articles such as Fries, Miller, and Perraudin (1997), Mello and Parsons (1992), Mello, Parsons, and Triantis (1995), and Mauer and Ott (2000), assume that the choice of debt levels balances the tax advantage of debt against the agency cost investigated by Myers. However, unlike this article, they assume that the investment costs are both fully irreversible and constant over time; and therefore, they focus on issues different from those of this article. Fries et al. investigate the relationship between the elasticity of demand and the choice of debt levels in competitive equilibrium. Mello and Parsons analyze how debt financing affects the operating decision of a mine. Mello et al. show that a firm can hedge exchange rate exposure to mitigate the agency problem investigated by Myers. Mauer and Ott compare financing and investment decisions of a firm that bears the agency cost investigated by Myers with those of a firm without this agency cost.

This article is organized as follows. The next section sets up the basic model. The third section derives both a firm's capacity decision in period 2 and the solvent region in this same

\footnotetext{
${ }^{2}$ This may be due to limited land, natural resource reserves, or the need for a permit that is in short supply (Abel et al. 1996).

${ }^{3}$ This may be due to asset specificity, the "lemons" problem, or governmental regulations (Dixit and Pindyck 1994, p.3).

${ }^{4}$ Loss carry-forward or loss carry-backward will make losses exhibit partial offset. I consider the polar case where losses exhibit full offset here.

${ }^{5}$ Bankruptcy costs may include legal fees, court costs, and a loss of revenue if the firm is prohibited to operate. See related studies by Altman (1984), Haugan and Senbet (1978), and Warner (1977).
} 
period. The fourth section breaks down equity value in period 1 into option and non-option value terms, and relates growth option values to the purchase price of capital in period 2. The firm's period 1 capacity decision is then characterized in terms of q-theory, and the effect of leverage on this decision is also analyzed. The fifth section derives debt value in period 1. The sixth section uses the results in the preceding sections to examine the number of bonds a firm should issue when total firm value is maximized. The relationship between the firm's choice of debt levels and each of the purchase and the resale price of capital in period 2 is then explored. The seventh section employs plausible parameter values to investigate the effect of a rise in either the purchase or resale price of capital in period 2 on the choice of debt levels, the choice of period 1 capacity, the probability of bankruptcy, total firm value, and the debt-to-firm value ratio. The last section presents the concluding remarks.

\section{The Model}

Abel, Dixit, Eberly, and Pindyck (1996) build a two-period model where a firm is both free of taxation and all-equity financed. The firm chooses an initial level of capacity and faces both rising cost of investment and declining salvage value in the later period. Abel et al. interpret opportunities for investment or disinvestment to the firm as options on its assets and analyze how these options are related to the firm's initial capacity decision. I introduce both taxation and debt financing into this two-period setting. In period 1, a firm issues bonds and then installs an initial capacity $K_{1}$ at unit cost $b$, and receives a return equal to $r\left(K_{1}\right)$. The return to capital minus the investment costs in period $1, r\left(K_{1}\right)-b K_{1}$, yields the net return to capital in the same period. The marginal return to period 1 capital, $r_{K_{1}}\left(K_{1}\right)$, is both positive for finite values of $K_{1}$ and lower as more period 1 capital is employed. The Inada conditions are satisfied, i.e., $\lim _{K_{1} \rightarrow 0} r_{K_{1}}\left(K_{1}\right)=\infty$, and $\lim _{K_{1} \rightarrow \infty} r_{K_{1}}\left(K_{1}\right)=0$.

Uncertainty arises at the beginning of period 2 . The uncertainty in period 2 is described by a disturbance term $e_{2}$ that affects the period 2 return to capital $R\left(K_{2}, e_{2}\right)(\geq 0)$, which is strictly increasing with $e_{2}$; the term $K_{2}$ is the firm's capacity in period 2, and the term $e_{2}$ is distributed over the interval $(-\infty,+\infty)$ with a cumulative distribution $F\left(e_{2}\right)$. The marginal return to capital in period 2, $R_{K_{2}}\left(K_{2}, e_{2}\right)$, satisfies the following conditions. First, $R_{K_{2}}\left(K_{2}, e_{2}\right)$ is positive for finite values of $K_{2}$. Second, $\partial R_{K_{2}}\left(K_{2}, e_{2}\right) / \partial e_{2}>0$ and $\partial R_{K_{2}}\left(K_{2}, e_{2}\right) / \partial K_{2}<0$, i.e., in period 2, a higher marginal return to capital is associated with either a better state or a lower capacity. Finally, the Inada conditions are obeyed; i.e., $\lim _{K_{2} \rightarrow 0} r_{K_{2}}\left(K_{2}, e_{2}\right)=\infty$ and $\lim _{K_{2} \rightarrow \infty} r_{K_{2}}\left(K_{2}, e_{2}\right)=0$.

I assume that the firm is acting in the interest of its equityholders after debt is in place. To allow the firm to bear the agency cost investigated by Myers (1977), I also assume that the firm is obliged to pay debtors the par value of outstanding bonds, denoted by $B$, after the uncertainty in period 2 is resolved. If the state of nature in period 2 is good enough, the firm will decide a new level of period 2 capacity and then pay the debtors off; otherwise, the firm will declare bankruptcy and then transfer assets to the debtors. After bankruptcy, debtholders will control the firm, reflecting the "absolute priority" of debt claims. Two possibilities will then arise: (i) debtholders cease to operate the firm; and therefore, they receive a value equal to the salvage value of installed capital; and (ii) debtholders continue to operate the firm by choosing a new level of capacity. The former, which corresponds to the worst outcome for debtholders, is adopted by Jou (2001). The latter, which corresponds to the best outcome for debtholders, is adopted by Mauer and Ott (2000) and will also be adopted in what follows. Furthermore, following Brander and Lewis (1986), I will abstract from the costs associated with bankruptcy. 
Suppose that $b_{h}$, the period 2 purchase price of capital, exceeds $b$, the period 1 purchase price of capital. Furthermore, suppose that $b_{l}$, the period 2 resale price of capital, is less than $b$. Denote $U_{2}\left(K_{1}, K_{2}\right)$ as the firm's period 2 value before paying both taxes and debt obligations; then

$$
U_{2}\left(K_{1}, K_{2}\right)=R\left(K_{2}, e_{2}\right)-1_{\left[K_{2}>K_{1}\right]} b_{h}\left(K_{2}-K_{1}\right)+1_{\left[K_{1}>K_{2}\right]} b_{l}\left(K_{1}-K_{2}\right),
$$

where $1_{[\cdot]}$ is an indicator function which is equal to one if the condition within [·] is satisfied, and zero otherwise. Equation (1) shows that $U_{2}\left(K_{1}, K_{2}\right)$ is equal to either (i) the period 2 pre-tax return to capital alone if $K_{2}=K_{1}$, (ii) the period 2 pre-tax return to capital minus the expansion costs if $K_{2}>K_{1}$, or (iii) the period 2 pre-tax return to capital plus the resale revenues if $K_{1}>K_{2}$.

Consider a firm that must pay both taxes and debt obligations. Denote $\tau(0<\tau<1)$ as the fixed corporate income tax rate applicable to the firm's taxable income in both periods 1 and 2 . Furthermore, assume that debt obligations in period 2 are tax deductible, ${ }^{6}$ and losses in both periods 1 and 2 are fully offset. Equity value in period 1 is then given by

$$
\pi_{1 E}\left(K_{1}\right)=(1-\tau)\left[r\left(K_{1}\right)-b K_{1}\right] .
$$

After the true state in period 2 is revealed, the firm is obliged to pay debtors the par value of outstanding bonds $B$. In period 2, the firm's equityholders have already received an amount equal to $\pi_{1 E}\left(K_{1}\right)$ given by (2), and they do not need to transfer this amount to the firm's debtholders no matter whether bankruptcy occurs. Accordingly, the limited liability of equity suggests that the relative magnitude between $U_{2}\left(K_{1}, K_{2}\right)$ given by (1) and $B$ determines whether the shareholderoriented firm will declare bankruptcy in period 2. Two cases will then arise. First, $U_{2}\left(K_{1}, K_{2}\right) \geq B$ so that the firm will pay the debtors off. Accordingly, debt value in this period, $\pi_{2 D}\left(K_{1}, K_{2}\right)$, is equal to $B$, and equity value in period $2, \pi_{2 E}\left(K_{1}, K_{2}\right)$, is equal to $(1-\tau)\left[U_{2}\left(K_{1}, K_{2}\right)-B\right]$. Second, $U_{2}\left(K_{1}, K_{2}\right)<B$ so that the firm is unable to pay the debtors off. Accordingly, the firm will go bankrupt, and therefore, debt value in period $2, \pi_{2 D}\left(K_{1}, K_{2}\right)$, is equal to $U_{2}\left(K_{1}, K_{2}\right)$. In addition, due to limited liability of equity, equity value in period $2, \pi_{2 E}\left(K_{1}, K_{2}\right)$, and the amount of taxation are both equal to zero. Pooling all above information yields

$$
\begin{gathered}
\pi_{2 E}\left(K_{1}, K_{2}\right)=(1-\tau) \max \left[U_{2}\left(K_{1}, K_{2}\right)-B, 0\right], \\
\pi_{2 D}\left(K_{1}, K_{2}\right)=\min \left[U_{2}\left(K_{1}, K_{2}\right), B\right] .
\end{gathered}
$$

Now consider the firm's situation in period 1 . Leveraged equity value in period 1 , denoted by $V_{1 E}\left(K_{1}\right)$, consists of two parts: (i) the net return to capital in period 1 given by $\pi_{1 E}\left(K_{1}\right)$ in (2); and (ii) the period 1 expected present value of equity in period 2 evaluated at the optimal level of period 2 capacity given by $\theta E_{1} V_{2 E}\left(K_{1}\right)=\theta E_{1} \max _{K_{2}} \pi_{2 E}\left(K_{1}, K_{2}\right)$; the term $\theta$ is the (risk-adjusted) discount factor and $E_{1}$ is the operator of expectation taken at $t=1$. In other words, equity value in period 1 is given by

$$
V_{1 E}\left(K_{1}\right)=\pi_{1 E}\left(K_{1}\right)+\theta E_{1} V_{2 E}\left(K_{1}\right) .
$$

\footnotetext{
${ }^{6}$ As suggested by Myers (1977, Appendix), the tax authority may allow deductions on some maximum interest rate $\lambda(0<\lambda \leq 1)$ so that the maximum attainable tax shield is $\lambda \tau B$. In what follows, I will impose $\lambda=1$ for ease of exposition.
} 
In period 1 , the limited liability of equity suggests that equity value should be non-negative, i.e., the constraint $V_{1 E}\left(K_{1}\right) \geq 0$ should be satisfied. Finally, denote $V_{1 D}\left(K_{1}\right)$ as debt value in period 1 , then

$$
V_{1 D}\left(K_{1}\right)=\theta E_{1} V_{2 D}\left(K_{1}\right)
$$

The term, $\theta E_{1} V_{2 D}\left(K_{1}\right)=\theta E_{1} \max _{K_{2}} \pi_{2 D}\left(K_{1}, K_{2}\right)$, is the period 1 expected present value of debt in period 2 evaluated at the optimal level of period 2 capacity, where $\pi_{2 D}\left(K_{1}, K_{2}\right)$ is given by (3b).

\section{The Solvent Region in Period 2}

In this section, I will first derive the period 2 capacity decision of the firm considered by Abel et al. (1996), taking the firm's period 1 capacity as given. I will then do the same thing for a firm that must pay both taxes and debt obligations in period 2, taking both the firm's financial structure and its period 1 capacity as given. Given that the firm acts in the interest of its equityholders after debt is in place, the firm is thus concerned with the solvent region in period 2, i.e., the range of states over which the pre-tax net return to capital in period 2 more than offsets the par value of outstanding bonds. I will examine how this solvent region is affected by a change in the capacity in period 1, the debt level, and both the purchase and the resale price of capital in period 2.

Consider the firm investigated by Abel et al. (1996). Define two critical values of $e_{2}, e_{2 h}$, and $e_{2 l}$, as

$$
\left.R_{K_{2}}\left(K_{2}, e_{2 h}\right)\right|_{K_{2}=K_{1}}=b_{h} \text { and }\left.R_{K_{2}}\left(K_{2}, e_{2 l}\right)\right|_{K_{2}=K_{1}}=b_{l} .
$$

Assuming that the firm neither purchases nor sells capital during period 2, $e_{2 h}$ is defined as the value of $e_{2}$ for which the marginal return to capital in period 2 is equal to the purchase price of capital in this same period. The term $e_{2 l}$ is defined as the value of $e_{2}$ for which the marginal return to capital in period 2 is equal to the resale price of capital in this same period. After $e_{2}$ is known, the capital stock will be adjusted to a new optimal level, which I write as $K_{2}\left(e_{2}\right)$. The choice of period 2 capital stock is obtained by setting the derivative of $U_{2}\left(K_{1}, K_{2}\right)$ given by (1) with respect to $K_{2}$ equal to zero. The states of nature in period 2 can then be classified into three regions: $e_{2}>e_{2 h}, e_{2 l}>e_{2}$, and $e_{2 h} \geq e_{2} \geq e_{2 l}$. First, when $e_{2}>e_{2 h}$, it is optimal to purchase capital until the marginal return to capital in period 2 equals the purchase price of capital in this same period, so $K_{2}\left(e_{2}\right)$ is given by $R_{K_{2}}\left(K_{2}\left(e_{2}\right), e_{2}\right)=b_{h}$. Second, when $e_{2 l}>e_{2}$, it is optimal to sell capital until the marginal return to capital in period 2 equals the resale price of capital in this same period, so $K_{2}\left(e_{2}\right)$ is given by $R_{K_{2}}\left(K_{2}\left(e_{2}\right), e_{2}\right)=b_{1}$. Finally, when $e_{2 h} \geq e_{2} \geq e_{2 l}$, it is optimal to neither purchase nor sell capital, so $K_{2}\left(e_{2}\right)=K_{1}$. It is obvious that the marginal return to capital in period 2 will lie between a floor, $b_{l}$, and a ceiling, $b_{h}$.

Consider a firm that both faces taxation and acts in the interest of its equityholders after debt is in place. Accordingly, the firm will choose a level of capacity in period 2 to maximize equity value in period $2, \pi_{2 E}\left(K_{1}, K_{2}\right)$ given by (3a). Setting the derivative of this equity value with respect to $K_{2}$ equal to zero yields the firm's choice of capacity in period 2, which resembles that investigated by Abel et al. (1996) when the realized state has a value of $e_{2}$ larger than a cutoff value.

Incorporating the firm's decision in period 2 yields this cutoff value. Suppose that $\hat{e}_{2}$ denotes 
the break-even value of $e_{2}$ assuming that the firm does not purchase nor sell capital in period 2, i.e.,

$$
R\left(K_{1}, \hat{e}_{2}\right)-B=0
$$

where $R\left(K_{1}, \hat{e}_{2}\right)$ denotes the value of $R\left(K_{2}, e_{2}\right)$ evaluated at $K_{2}=K_{1}$ and $e_{2}=\hat{e}_{2}$. Three cases will then arise: $e_{2 h} \geq \hat{e}_{2} \geq e_{2 l}, \hat{e}_{2}>e_{2 h}$, and $e_{2 l}>\hat{e}_{2}$. First, if $e_{2 h} \geq \hat{e}_{2} \geq e_{2 l}$, then the premise is verified so that $\hat{e}_{2}$ will also be the cutoff value of $e_{2}$ relevant to a shareholder-oriented firm. I will call this cutoff value $\hat{e}_{2 \mathrm{~m}}$. Accordingly, the solvent region in period 2 is given by $e_{2}>\hat{e}_{2 m}$. Second, if $\hat{e}_{2}>e_{2 h}$, a shareholder-oriented firm will be better off if it expands rather than maintains capacity at $e_{2}=\hat{e}_{2}$. As a result, the solvent region in period 2 should extend beyond $\hat{e}_{2}$, and the associated cutoff value, denoted by $\hat{e}_{2 h}$, satisfies the equation given by

$$
R\left(K_{2}\left(\hat{e}_{2 h}\right), \hat{e}_{2 h}\right)-b_{h}\left(K_{2}\left(\hat{e}_{2 h}\right)-K_{1}\right)-B=0 .
$$

The solvent region in period 2 is given by $e_{2}>\hat{e}_{2 h}$. Finally, if $e_{2 l}>\hat{e}_{2}$, a shareholder-oriented firm will be better off if it contracts rather than maintains capacity at $e_{2}=\hat{e}_{2}$. As a result, the solvent region in period 2 should extend beyond $\hat{e}_{2}$, and the associated cutoff value, denoted by $\hat{e}_{2 l}$, satisfies the equation given by

$$
R\left(K_{2}\left(\hat{e}_{2 l}\right), \hat{e}_{2 l}\right)+b_{l}\left(K_{2}-K_{2}\left(\hat{e}_{2 l}\right)\right)-B=0 .
$$

Accordingly, the solvent region in period 2 is given by $e_{2}>\hat{e}_{2 l}$. Figure 1 presents the relationship among $e_{2 h}, e_{2 l}, \hat{e}_{2}, \hat{e}_{2 m}, \hat{e}_{2 h}$, and $\hat{e}_{2 l}$.

FIGURE 1

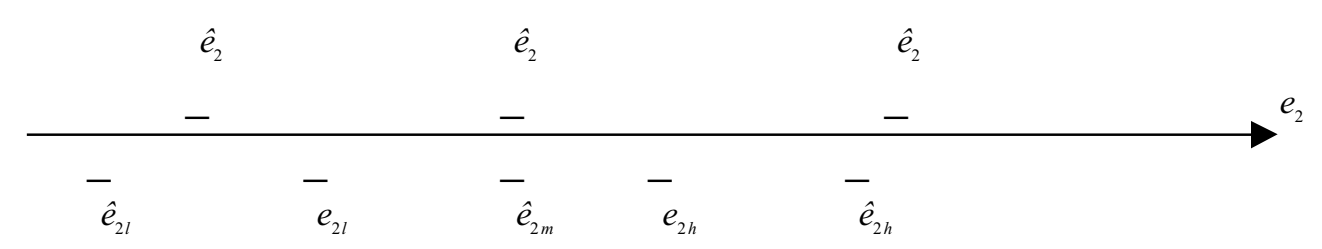

Equations (6a)-(6c) implicitly define the dependence of $\hat{e}_{2 m}, \hat{e}_{2 h}$, and $\hat{e}_{2 l}$ on $K_{1}, B, b_{h}$, and $b_{l}$. The following comparative static results are useful later:

$$
\begin{gathered}
\frac{\partial \hat{e}_{2 m}}{\partial K_{1}}=\frac{-R_{K_{2}}\left(K_{1}, \hat{e}_{2 m}\right)}{R_{e_{2}}\left(K_{1}, \hat{e}_{2 m}\right)}<0, \\
\frac{\partial \hat{e}_{2 h}}{\partial K_{1}}=\frac{-b_{h}}{R_{e_{2}}\left(K_{2}\left(\hat{e}_{2 h}\right), \hat{e}_{2 h}\right)}<0, \\
\frac{\partial \hat{e}_{2 l}}{\partial K_{1}}=\frac{-b_{l}}{R_{e_{2}}\left(K_{2}\left(\hat{e}_{2 l}\right), \hat{e}_{2 l}\right)}<0,
\end{gathered}
$$




$$
\begin{gathered}
\frac{\partial \hat{e}_{2 m}}{\partial B}=\frac{1}{R_{e_{2}}\left(K_{1}, \hat{e}_{2 m}\right)}>0, \\
\frac{\partial \hat{e}_{2 h}}{\partial B}=\frac{1}{R_{e_{2}}\left(K_{2}\left(\hat{e}_{2 h}\right), \hat{e}_{2 h}\right)}>0, \\
\frac{\partial \hat{e}_{2 l}}{\partial B}=\frac{1}{R_{e_{2}}\left(K_{2}\left(\hat{e}_{2 l}\right), \hat{e}_{2 l}\right)}>0, \\
\frac{\partial \hat{e}_{2 h}}{\partial b_{h}}=\frac{K_{2}\left(\hat{e}_{2 h}\right)-K_{1}}{R_{e_{2}}\left(K_{2}\left(\hat{e}_{2 h}\right), \hat{e}_{2 h}\right)}>0, \\
\frac{\partial \hat{e}_{2 l}}{\partial b_{l}}=\frac{K_{2}\left(\hat{e}_{2 l}\right)-K_{1}}{R_{e_{2}}\left(K_{2}\left(\hat{e}_{2 l}\right), \hat{e}_{2 l}\right)}<0 .
\end{gathered}
$$

The negative sign of (7a)-(7c) indicates that a firm that installs a larger capacity in period 1 will have a larger solvent region in period 2 . The positive sign of $(8 \mathrm{a})-(8 \mathrm{c})$ suggests that a firm issuing more bonds will have a smaller solvent region in period 2. Furthermore, by (1), if a firm both purchases capital at a higher price in period $2\left(b_{h}\right.$ is higher $)$ and decides to expand capacity at the state where the firm is on the verge of bankruptcy in period 2, then its pre-tax net return to capital in period 2 will be lower. By (9), the firm will then have a smaller solvent region in period 2. Finally, by (1), if a firm both sells installed capital at a higher price in period 2 ( $b_{l}$ is higher) and decides to contract capacity at the state where the firm is on the verge of bankruptcy, then its pre-tax net return to capital in period 2 will be higher. By (10), the firm will then have a larger solvent region in period 2.

\section{The Firm's Period 1 Capacity Decision}

This section proceeds as follows. First, I will calculate the period 1 expected present value of equity in period 2. This calculated value, plus the net return to capital in period 1 given by (2), yields equity value in period $1, V_{1 E}\left(K_{1}\right)$ given by (4a). Following Abel et al. (1996), I will break down $V_{1 E}\left(K_{1}\right)$ into four parts: the value of assets already in place, the value of debt obligations, the growth option value to expand capacity, and the put option value to contract capacity. Second, I will derive the firm's choice of period 1 capacity in terms of q-theory (Tobin, 1969), taking its financial structure as predetermined, and then investigate how a change in leverage affects this choice.

I start by deriving the period 1 expected value of equity in period 2, the second term without the multiplier $\theta$ in (4a), i.e., $E_{1} V_{2 E}\left(K_{1}\right)=E_{1} \max _{K_{2}} \pi_{2 E}\left(K_{1}, K_{2}\right)$. Substituting (3a) into this expression yields $E_{1} V_{2 E}\left(K_{1}\right)$ as given by $(1-\tau) E_{1} \max _{K_{2}}\left[U_{2}\left(K_{1}, K_{2}\right)-B, 0\right]$. Let $Z\left(K_{1}, e_{2}\right)$ denote $U_{2}\left(K_{1}, K_{2}\right)$ given by (1) at the state where the firm decides to expand capacity in period 2 $\left(K_{2}>K_{1}\right)$. Let $Y\left(K_{1}, e_{2}\right)$ denote $U_{2}\left(K_{1}, K_{2}\right)$ at the state where the firm decides to contract capacity in period $2\left(K_{1}>K_{2}\right)$. In other words,

$$
\left.Z\left(K_{1}, e_{2}\right)=R\left(K_{2}\left(e_{2}\right), e_{2}\right)-b_{h}\left(K_{2}\left(e_{2}\right)-K_{1}\right)\right), \quad Y\left(K_{1}, e_{2}\right)=R\left(K_{2}\left(e_{2}\right), e_{2}\right)+b_{l}\left(K_{1}-K_{2}\left(e_{2}\right)\right) .
$$

Combining the rule for the choice of capacity in period 2 derived in section III with (11) yields

$$
E_{1} V_{2 E}\left(K_{1}\right)=(1-\tau)\left[\int_{\hat{e}_{2 m}}^{e_{2 H}}\left(R\left(K_{1}, e_{2}\right)-B\right)+\int_{e_{2 n}}^{\infty}\left(Z\left(K_{1}, e_{2}\right)-B\right)\right] d F\left(e_{2}\right)
$$




$$
\begin{gathered}
E_{1} V_{2 E}\left(K_{1}\right)=(1-\tau) \int_{\hat{e}_{24}}^{\infty}\left(Z\left(K_{1}, e_{2}\right)-B\right) d F\left(e_{2}\right), \\
E_{1} V_{2 E}\left(K_{1}\right)=(1-\tau)\left[\int_{\hat{e}_{21}}^{e_{21}}\left(Y\left(K_{1}, e_{2}\right)-B\right) d F\left(e_{2}\right)+\int_{e_{21}}^{e_{24}}\left(R\left(K_{1}, e_{2}\right)-B\right) d F\left(e_{2}\right)+\int_{e_{24}}^{\infty}\left(Z\left(K_{1}, e_{2}\right)-B\right) d F\left(e_{2}\right)\right],
\end{gathered}
$$

if the firm decides to either maintain capacity (12a), expand capacity (12b), or contract capacity (12c), at the state where the firm is on the verge of bankruptcy in period 2.

\section{Costly Expansion and Growth Option Values}

Equity value in period $1, V_{1 E}\left(K_{1}\right)$, is equal to the term $\theta E_{1} V_{2 E}\left(K_{1}\right)$ given by (12a)-(12c) plus the term $\pi_{1 E}\left(K_{1}\right)$ given by (2). Following Abel et al. (1996) yields

$$
V_{1 E}\left(K_{1}\right)=G_{i}\left(K_{1}\right)+C_{i}\left(K_{1}\right)+P_{i}\left(K_{1}\right)-H_{i}\left(K_{1}\right)(i=m, h, l),
$$

where

$$
\begin{gathered}
G_{i}\left(K_{1}\right)=(1-\tau)\left[r\left(K_{1}\right)-b K_{1}+\theta \int_{\hat{e}_{21}}^{\infty} R\left(K_{1}, e_{2}\right) d F\left(e_{2}\right)\right], \\
C_{m}\left(K_{1}\right)=C_{l}\left(K_{1}\right)=(1-\tau) \theta \int_{e_{2 n}}^{\infty}\left[Z\left(K_{1}, e_{2}\right)-R\left(K_{1}, e_{2}\right)\right] d F\left(e_{2}\right)>0, \\
C_{h}\left(K_{1}\right)=(1-\tau) \theta \int_{e_{2 n}}^{\infty}\left[Z\left(K_{1}, e_{2}\right)-R\left(K_{1}, e_{2}\right)\right] d F\left(e_{2}\right)>0, \\
P_{m}\left(K_{1}\right)=P_{h}\left(K_{1}\right)=0, \\
P_{l}\left(K_{1}\right)=(1-\tau) \theta \int_{\hat{e}_{2 l}}^{e_{2 l}}\left[Y\left(K_{1}, e_{2}\right)-R\left(K_{1}, e_{2}\right)\right] d F\left(e_{2}\right)>0, \\
H_{i}\left(K_{1}\right)=(1-\tau) \theta\left[1-F\left(\hat{e}_{2 i}\right)\right] B>0 .
\end{gathered}
$$

The subscript $i=m, h$ or $l$ represents the case where the firm decides to maintain capacity (12a), expand capacity (12b), or contract capacity (12c) at the state where the firm is on the verge of bankruptcy in period 2. The term $G_{i}\left(K_{1}\right)$ given by $(13 \mathrm{~b})$ is the value of assets already in place, which is calculated under the assumption that the firm is able to neither purchase nor sell capital in period 2, i.e., $K_{2}=K_{1}$. The term $C_{i}\left(K_{1}\right)(i=m, h, l)$ given by both (13c) and (13d) is the value of the call option, i.e., the option to buy capital in period 2 at a price of $b_{h}$. The firm will choose to exercise this option if $e_{2}>e_{2 h}(i=m$ or $l)$ or $e_{2}>\hat{e}_{2 h}(i=h)$. I use this call option value to proxy the growth option value coined by Myers (1977). The term $P_{i}\left(K_{1}\right) \quad(i=m, h, l)$ given by both (13e) and (13f) is the value of the put option, i.e., the option to sell capital in period 2 at a price of $b_{l}$. The firm will choose to exercise this option if $e_{2 l}>e_{2}>\hat{e}_{2 l}(i=l)$. The subtracted term

$H_{i}\left(K_{1}\right)$ given by $(13 \mathrm{~g})$, which is the expected present value of the promised payments to debtholders in period 2, i.e., $(1-\tau) \theta\left[1-F\left(\hat{e}_{2 i}\right)\right] B$, represents the value of debt obligations. Partially differentiating $C_{i}\left(K_{1}\right) \quad(i=m, h, l)$ given by (13c) and (13d) with respect to $b_{h}$ yields Proposition 1 (The proof is omitted to save space). 
Proposition 1. A firm that purchases capital at a higher price in period 2 will have a lower growth option value. $^{7}$

\section{The q-theory Approach}

Given that a firm acts in the interest of its equityholders after debt is in place, the firm will choose a level of capacity in period 1 to maximize period 1 equity value, $V_{1 E}\left(K_{1}\right)$ in (4a). Assuming that an interior solution exists, the choice of period 1 capacity is obtained by setting $V_{1 E}\left(K_{1}\right)$ with respect to $K_{1}$ equal to zero, i.e.,

$$
\frac{\partial V_{1 E}\left(K_{1}\right)}{\partial K_{1}}=0 .
$$

Substituting both $\pi_{1 E}\left(K_{1}\right)$ given by (2) and $E_{1} V_{2 E}\left(K_{1}\right)$ given by (12a)-(12c) into the right-hand side of (4a), and then partially differentiating the result with respect to $K_{1}$ yields the explicit form of (14) as given by

$$
\begin{gathered}
(1-\tau) r_{K_{1}}\left(K_{1}\right)+(1-\tau) \theta\left\{\int_{\hat{e}_{2 m}}^{e_{2 h}} R_{K_{2}}\left(K_{1}, e_{2}\right) d F\left(e_{2}\right)+b_{h}\left[1-F\left(e_{2 h}\right)\right]\right\}=(1-\tau) b, \\
(1-\tau) r_{K_{1}}\left(K_{1}\right)+(1-\tau) \theta b_{h}\left[1-F\left(\hat{e}_{2 h}\right)\right]=(1-\tau) b, \\
(1-\tau) r_{K_{1}}\left(K_{1}, e_{1}\right)+(1-\tau) \theta\left\{b_{1}\left[F\left(e_{2 l}\right)-F\left(\hat{e}_{2 l}\right)\right]+\int_{e_{2 l}}^{e_{2 h}} R_{K_{2}}\left(K_{1}, e_{2}\right) d F\left(e_{2}\right)+b_{h}\left[1-F\left(e_{2 h}\right)\right]\right\}=(1-\tau) b,
\end{gathered}
$$

if the firm decides to maintain capacity (15a), expand capacity (15b), or contract capacity (15c) at the state where the firm is on the verge of bankruptcy in period 2. Among the three possible levels of capacity in period 1 that satisfy equations (15a)-(15c), the firm will choose the one that yields the highest equity value in period 1 .

Conditions (15a)-(15c) are written in terms of Tobin's q-theory, which states that the choice of period 1 capacity equates the marginal or shadow value of capital in period 1 (the left-hand side) to the marginal cost of capital in period 1 (the right-hand side). The former includes the after-tax marginal return to capital in period 1 (the first term) and the period 1 after-tax expected present value of the marginal return to capital in period 2 (the second term). In addition, the marginal cost of period 1 capital is equal to the term $1-\tau$ multiplied by the purchase price of capital in period 1 , $b$.

Proposition 2 follows from condition (14).

Proposition 2. (The Debt Overhang Problem) A firm that issues more bonds will install a smaller capacity in period 1 .

Proof. Let us denote $K_{1}^{*}$ as the $K_{1}$ value that satisfies condition (14). Totally differentiating this condition with respect to $B$ yields

$$
\frac{d K_{1}^{*}}{d B}=\frac{\Delta_{12}}{-\Delta_{11}}<0
$$

\footnotetext{
${ }^{7}$ Similarly, partially differentiating $P_{t}\left(K_{1}\right)$ given by (13f) with respect to $b_{t}$ yields the following result: a firm that sells capital at a higher price in period 2 will have a higher put option value if the firm decides to contract capacity at the state where the firm is on the verge of bankruptcy in period 2.
} 
where

$$
\begin{gathered}
\Delta_{11}=\frac{\partial^{2} V_{1 E}\left(K_{1}^{*}\right)}{\partial K_{1}^{2}}<0,{ }^{8} \\
\Delta_{12}=\frac{\partial^{2} V_{1 E}\left(K_{1}^{*}\right)}{\partial K_{1} \partial B}<0 .
\end{gathered}
$$

This completes the proof.

The intuition behind Proposition 2 is as follows: in period 2, a firm is unable to redeem its debt obligations in bad states of the world, i.e., in the bankrupt states where $e_{2}<\hat{e}_{2 i}(i=m, h, l)$, so that the equityholders' claims on the firm go to zero, and the debtholders become the residual claimants. In other words, debtholders become residual claimants in bad states because equity has limited liability. In contrast, equityholders will become residual claimants in good states of nature, i.e., in the solvent states where $e_{2}>\hat{e}_{2 i}(i=m, h, l)$.

By (8a)-(8c), an increase in debt causes $\hat{e}_{2 i}(i=m, h, l)$ to rise, indicating that the range of states where the firm becomes bankrupt in period 2 is expanded. This, together with the assumption that the marginal return to capital is positive in all states in period 2, indicates that some states with low marginal, yet positive, returns to capital in period 2 are moved from the solvent region to the bankrupt region. In other words, these vacated states which yield positive marginal returns to period 2 capital are no longer relevant to a shareholder-oriented firm. Accordingly, the firm would want to install a smaller capacity in period 1. An increase in debt thus induces a smaller capacity in period 1 .

The result in Proposition 2 resembles the "debt overhang" problem investigated by Myers (1977). However, Myers assumes that a firm chooses among many risky discrete investment projects which have the same class of risk, while I assume that a firm faces one risky continuous investment project. The result in Proposition 2 differs from that of Brander and Lewis (1986). In Brander and Lewis, a shareholder-oriented firm in a duopolistic market will take a more aggressive output strategy as the firm issues more bonds because a higher debt level will exclude some unproductive states which are no longer relevant to the firm.

\section{Debt Value In Period 1}

If potential debtholders are foresighted, then the firm can only sell the bonds at their true value. This true value is the period 1 expected present value of debt in period 2, i.e., $V_{1 D}\left(K_{1}\right)=\theta E_{1} V_{2 D}\left(K_{1}\right)=\theta E_{1} \max _{K_{2}} \pi_{2 D}\left(K_{1}, K_{2}\right)$, where $\pi_{2 D}\left(K_{1}, K_{2}\right)$ is given by (3b). To calculate $E_{1} V_{2 D}\left(K_{1}\right)$, we face a problem of maximizing debt value in period 2, as if debtholders were running the firm in this same period. Setting the derivative of debt value in period $2, \pi_{2 D}\left(K_{1}, K_{2}\right)$, with respect to $K_{2}$ equal to zero yields the debtholders' choice of capacity in period 2, which resembles that investigated by Abel et al. (1996) when the state of nature $e_{2}$ is smaller than the cut-off value of $e_{2}$, i.e., $\hat{e}_{2 i}(i=m, h, l)$ defined in (6a)-(6c).

The period 1 expected value of debt in period 2, $E_{1} V_{2 D}\left(K_{1}\right)$, includes two portions: (i) the integral of the optimized value of $U_{2}\left(K_{1}, K_{2}\right)$ over the region where the firm is insolvent; and (ii)

${ }^{8}$ This is the second-order condition for $K_{1}$ to be an interior solution. I will assume it holds in what follows. 
$B$ multiplied by the probability of the firm being solvent, i.e., $1-F\left(\hat{e}_{2 i}\right) \quad(i=m, h, l)$. The term $V_{1 D}\left(K_{1}\right)$, which is equal to $\theta E_{1} V_{2 D}\left(k_{1}\right)$, is thus given by

$$
\begin{gathered}
V_{1 D}\left(K_{1}\right)=\theta\left[\int_{-\infty}^{e_{2 t}} Y\left(K_{1}, e_{2}\right) d F\left(e_{2}\right)+\int_{e_{2 l}}^{\hat{e}_{2 m}} R\left(K_{1}, e_{2}\right) d F\left(e_{2}\right)\right]+\theta\left(1-F\left(\hat{e}_{2 m}\right)\right) B \\
V_{1 D}\left(K_{1}\right)=\theta\left[\int_{-\infty}^{e_{2 t}} Y\left(K_{1}, e_{2}\right) d F\left(e_{2}\right)+\int_{e_{2 l}}^{e_{2 t}} R\left(K_{1}, e_{2}\right) d F\left(e_{2}\right)+\int_{e_{2 h}}^{\hat{e}_{2 t}} Z\left(K_{1}, e_{2}\right) d F\left(e_{2}\right)\right]+\theta\left(1-F\left(\hat{e}_{2 h}\right)\right) B \\
V_{1 D}\left(K_{1}\right)=\theta \int_{-\infty}^{\hat{e}_{2 t}} Y\left(K_{1}, e_{2}\right) d F\left(e_{2}\right)+\theta\left(1-F\left(\hat{e}_{2 l}\right)\right) B
\end{gathered}
$$

if debtholders decide to either maintain capacity (17a), expand capacity (17b), or contract capacity $(17 \mathrm{c})$, at the state where the firm is on the verge of bankruptcy in period 2.

Partially differentiating $V_{1 D}\left(K_{1}\right)$ given by (17a)-(17c) with respect to $K_{1}$ yields

$$
\begin{gathered}
\frac{\partial V_{1 D}\left(K_{1}\right)}{\partial K_{1}}=\theta b_{l} F\left(e_{2 l}\right)+\theta \int_{e_{2 l}}^{\hat{e}_{2 n}} R_{K_{2}}\left(K_{1}, e_{2}\right) d F\left(e_{2}\right)>0 \\
\frac{\partial V_{1 D}\left(K_{1}\right)}{\partial K_{1}}=\theta b_{l} F\left(e_{2 l}\right)+\theta \int_{e_{2 l}}^{e_{2 h}} R_{K_{2}}\left(K_{1}, e_{2}\right) d F\left(e_{2}\right)+\theta b_{h}\left(F\left(\hat{e}_{2 h}\right)-F\left(e_{2 h}\right)\right)>0 \\
\frac{\partial V_{1 D}\left(K_{1}\right)}{\partial K_{1}}=\theta b_{l} F\left(\hat{e}_{2 l}\right)>0 .
\end{gathered}
$$

A firm that installs a larger capacity in period 1 will have a higher pre-tax net return to capital in period 2, $U_{2}\left(K_{1}, K_{2}\right)$ given by (1). Consequently, debt value in period $2, \pi_{2 D}\left(K_{1}, K_{2}\right)$, will be higher in the states where the firm is insolvent in this same period, but will be unchanged otherwise. By (18a)-(18c), debt value in period 1, which is the period 1 expected present value of debt in period 2, will thus be higher.

\section{The Choice of Debt Levels}

The previous sections have examined a firm's choice of capacity in period 1, taking its financial structure as given. This section will derive the condition for its choice of debt levels. ${ }^{9}$ These two choices should be solved jointly. The impacts of changes in both of the purchase and the resale price of capital in period 2 on these two choices are then derived.

A firm maximizes total firm value when issuing bonds, given that the firm and its creditors rationally expect consequences of debt financing on the choice of capacity in period 1, denoted by $K_{1}^{*}$. Total firm value in period $1, V_{1}\left(K_{1}^{*}\right)$, is the sum of equity value in period $1, V_{1 E}\left(K_{1}^{*}\right)$ given by $(4 \mathrm{a})$, and debt value in period $1, V_{1 D}\left(K_{1}^{*}\right)$ given by $(4 \mathrm{~b})$. In other words,

$$
V_{1}\left(K_{1}^{*}\right)=V_{1 E}\left(K_{1}^{*}\right)+V_{1 D}\left(K_{1}^{*}\right) \text {. }
$$

${ }^{9}$ This article abstracts from the costs associated with bankruptcy and other considerations of debt financing; e.g., bonds may either convey private information to capital markets, mitigate adverse selection effects, or affect the outcome of corporate control contests (see, e.g., Harris and Raviv 1991). 
The marginal effect of an increase in debt on total firm value in period 1 is given by the total derivative of $V_{1}\left(K_{1}^{*}\right)$ with respect to $B$, i.e.,

$$
\frac{d V_{1}\left(K_{1}^{*}\right)}{d B}=\left(\frac{\partial V_{1 E}\left(K_{1}^{*}\right)}{\partial K_{1}}\right) \frac{d K_{1}^{*}}{d B}+\left(\frac{\partial V_{1 D}\left(K_{1}^{*}\right)}{\partial K_{1}}\right) \frac{d K_{1}^{*}}{d B}+\frac{\partial V_{1}\left(K_{1}^{*}\right)}{\partial B}
$$

The three terms on the right-hand side of (20) have the following meanings. The first one represents the effect of a higher leverage on equity value in period 1 through inducing a smaller capacity in period 1. By condition (14), this effect will vanish. The second one represents the effect of a higher leverage on debt value in period 1 through inducing a smaller capacity in period 1. This term, which is negative, as suggested by combining Proposition 2 and (18a)-(18c), indicates that a higher leverage exacerbates the conflict of interest between equity and debt holders, and therefore, lowers debt value in period 1. The final term represents the expected present value of the net return to capital in period 2 shielded from taxation per unit increase of bonds, and can be expressed as

$$
\tau \theta\left(1-F\left(\hat{e}_{2 i}\right)\right)
$$

where the subscript $i$ is equal to $m, h$, or $l$ if a shareholder-oriented firm decides to either maintain, expand, or contract capacity at the state where the firm is on the verge of bankruptcy in period 2. The choice of debt levels is derived by setting $d V_{1}\left(K_{1}^{*}\right) / d B$ given by (20) equal to zero, i.e.,

$$
\frac{\partial V_{1 D}\left(K_{1}^{*}\right)}{\partial K_{1}} \frac{d K_{1}^{*}}{d B}+\frac{\partial V_{1}\left(K_{1}^{*}\right)}{\partial B}=0 .
$$

By (22), a firm's choice of debt levels balances the marginal tax shield benefit against the marginal agency cost associated with the "debt overhang" problem.

This article considers a firm that decides debt levels first, followed by deciding an initial capacity. The former decision is characterized by condition (14), while the latter is characterized by condition (22). These two conditions jointly determine two endogenously variables: $K_{1}^{*}(\cdot)$ and $B^{*}(\cdot)$, where the symbol '.' represents the underlying exogenous variables. Equity value in period 1 given by (4a), and debt value in period 1 given by (4b), can thus be rewritten as $V_{1 E}\left(K_{1}^{*}(\cdot), B^{*}(\cdot),\right)$ and $V_{1 D}\left(K_{1}^{*}(\cdot), B^{*}(\cdot), \cdot\right)$, respectively. Accordingly, condition (14) can be rewritten as

$$
\frac{\partial V_{1 E}\left(K_{1}^{*}(\cdot), B^{*}(\cdot), \cdot\right)}{\partial K_{1}}=0 .
$$

Equation (14') implicitly defines the dependence of $K_{1}^{*}$ on $B^{*}$. Totally differentiating (14') with respect to $B^{*}$ and rearranging yields

$$
\frac{d K_{1}^{*}}{d B^{*}}=\frac{\Delta_{12}}{-\Delta_{11}}<0
$$

where

$$
\Delta_{11}=\frac{\partial^{2} V_{1 E}\left(K_{1}^{*}(\cdot), B^{*}(\cdot),\right)}{\partial K_{1}^{2}}<0
$$




$$
\Delta_{12}=\frac{\partial^{2} V_{1 E}\left(K_{1}^{*}(\cdot), B^{*}(\cdot), \cdot\right)}{\partial K_{1} \partial B}<0
$$

The negative sign given by (16a'), which restates the "debt overhang" effect of Proposition 2, is depicted by line $X X$ in Figure 2.

Condition (22) can also be rewritten as

$$
\frac{\partial V_{1 D}\left(K_{1}^{*}(\cdot), B^{*}(\cdot),\right)}{\partial K_{1}} \frac{d K_{1}^{*}}{d B^{*}}+\frac{\partial V_{1}\left(K_{1}^{*}(\cdot), B^{*}(\cdot), \cdot\right)}{\partial B}=0
$$

Condition (22') implicitly defines the dependence of $B^{*}$ on $K_{1}^{*}$. Totally differentiating (22') with respect to $K_{1}^{*}$ yields

$$
\frac{d B^{*}}{d K_{1}^{*}}=\frac{\Delta_{21}}{-\Delta_{22}}>0
$$

where

$$
\begin{gathered}
\Delta_{21}=\frac{\partial^{2} V_{1 D}\left(K_{1}^{*}(\cdot), B^{*}(\cdot),\right)}{\partial K_{1}^{2}} \frac{d K_{1}^{*}}{d B^{*}}+\frac{\partial^{2} V_{1}\left(K_{1}^{*}(\cdot), B^{*}(\cdot), \cdot\right)}{\partial B \partial K_{1}}>0, \\
(-) \quad(-) \quad(+) \\
\Delta_{22}=\frac{\partial^{2} V_{1 D}\left(K_{1}^{*}(\cdot), B^{*}(\cdot),\right)}{\partial K_{1} \partial B} \frac{d K_{1}^{*}}{d B^{*}}+\frac{\partial V_{1 D}\left(K_{1}^{*}(\cdot), B^{*}(\cdot),\right)}{\partial K_{1}} \frac{d^{2} K_{1}^{*}}{d B^{* 2}}+\frac{\partial^{2} V_{1}\left(K_{1}^{*}(\cdot), B^{*}(\cdot), \cdot\right)}{\partial B^{2}}<0 .{ }^{10}(23 \mathrm{c}) \\
(+) \quad(-) \quad(+) \quad\left(\frac{\geq}{<}\right)
\end{gathered}
$$

By (23b), a larger capacity in period 1 reduces the marginal agency cost of debt (the first term), while raising the tax shield benefit of debt (the second term); and therefore, debt capacity will be higher. The positive sign given by (23a), which is depicted by line $Y Y$ in Figure 2, captures this relationship.

The results in Propositions 3 and 4 will follow from simultaneously solving both conditions $\left(14^{\prime}\right)$ and $\left(22^{\prime}\right)$.

Proposition 3. Suppose that a firm decides to either maintain or contact capacity at the state where the firm is on the verge of bankruptcy in period 2. The firm that purchases capital at a higher price in period 2 will then issue more bonds if the debt overhang problem the firm faces becomes either less severe or unchanged.

The intuition behind Proposition 3 is as follows (see the Appendix). A firm's capacity decision in period 2 can be classified into three cases: at the state on the verge of bankruptcy in period 2, the

firm decides to either (i) maintain, (ii) expand, or (iii) contract capacity. Suppose that the firm purchases capital at a higher price in period 2. Given the firm's choice of debt levels, its incentive to install capacity in period 1 will be raised because the ceiling on the marginal return to capital in period 2 becomes higher. This is precisely the only effect under cases (i) and (iii). Suppose that we start from an initial equilibrium point $E_{a}$ in Figure 2, which is the intersection of lines $X X$ and

${ }^{10}$ For both $\Lambda_{1}(\cdot)$ and $B(\cdot)$ to be an interior solution, it is required that $\Delta_{22}<\mathrm{U}$. I will assume that this condition holds (e.g., if $a \Lambda_{1} / O D>U$ ) in what follows. 
FIGURE 2: A RISE IN $b_{h}$ OR $b_{l}$

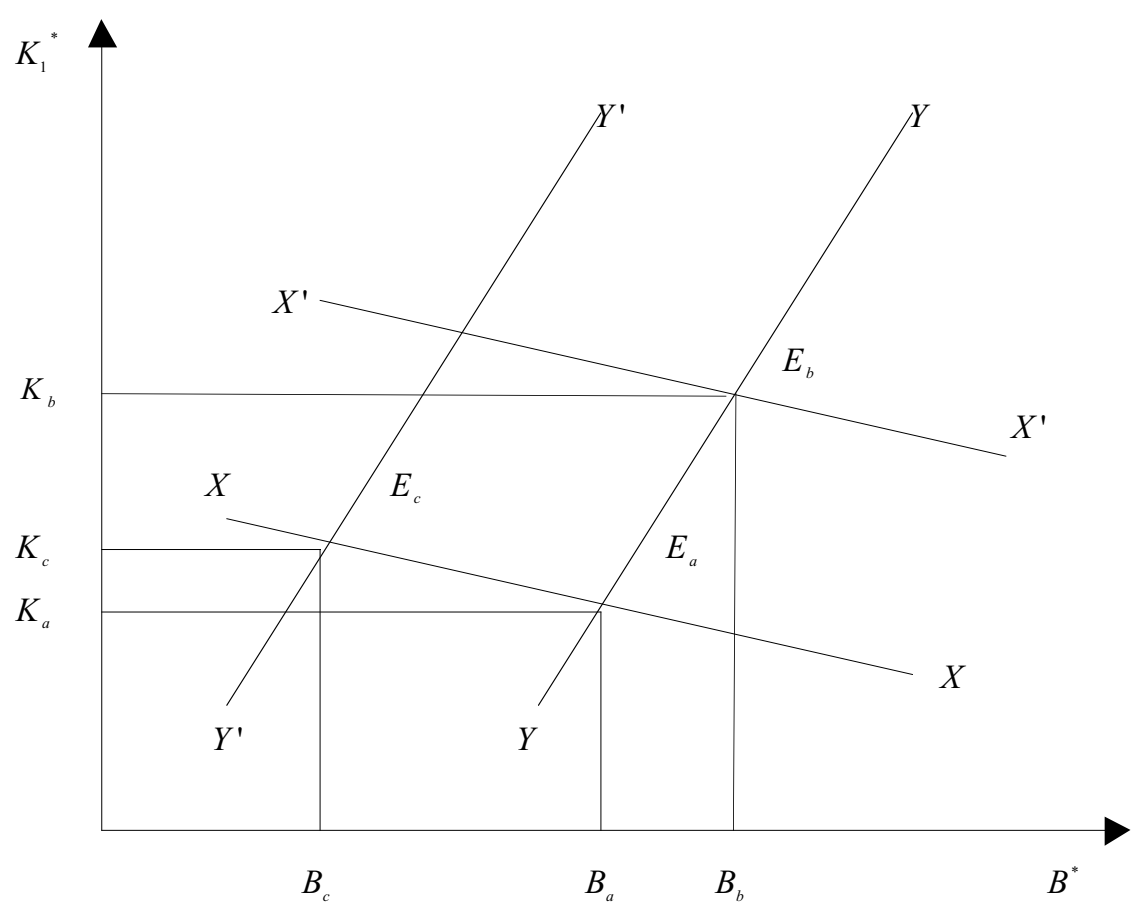

$Y Y$. This effect is then captured by a shift from line $X X$ to line $X^{\prime} X^{\prime}$. However, under case (ii), the sign of $\Delta_{13}$ in equation (A3) suggests that the net effect on the firm's incentive to install capacity in period 1 is ambiguous because an offsetting effect as follows will arise: by (9), a firm that purchases capital in period 2 at a higher price will have a smaller solvent region in period 2; and therefore, the firm will have a lower incentive to install capacity in period 1.

Given the firm's choice of period 1 capacity, consider the effect of a rise in the purchase price of capital in period 2 on the firm's incentive to issue bonds. This effect is determined by the sign of $\Delta_{23}$ in equation (A4). Under cases (i) and (iii), on the right-hand side of (A4), the last two terms are both equal to zero, and thus the first term alone decides the sign of $\Delta_{23}$. This first term captures the effect of a rise in the purchase price of capital in period 2 on the marginal agency cost of debt, and has the same sign as that of $\partial\left(d K_{1}^{*} / d B^{*}\right) / \partial b_{h}$, i.e., the impact of a rise in the purchase price of capital in period 2 on the "debt overhang" problem.

Suppose that $\partial\left(d K_{1}^{*} / d B^{*}\right) / \partial b_{h} \geq 0$, i.e. the debt overhang problem a firm faces becomes either less severe or unchanged as the firm purchases period 2 capital at a higher price. Line $Y Y$ will then either shift rightward or remain unchanged. The new equilibrium point, which is determined by the intersection of line $X^{\prime} X^{\prime}$ and this shift of line $Y Y$, indicates that the firm's choice of debt levels will be either equal to or greater than $B_{b}$, and will thus be greater than $B_{a}$, the initial choice of debt levels. The result in Proposition 3 will then follow.

The result of Proposition 3 can be compared with that of Myers (1977). Myers conjectures that the marginal agency cost of debt financing that results from the "debt overhang" problem will be higher as a firm has more growth opportunities. Consequently, the firm's debt capacity will be 
inversely related to its growth option value. Myers does not validate this conjecture because he does not explicitly endogenize capital structure decision. In contrast, in my framework, by Proposition 1, if a firm purchases capital in period 2 at a higher price, its growth option value will be lower. Proposition 3 then delineates a case in which the negative relationship between leverage and growth opportunities holds. For all other cases, by (A6), it is unclear whether Myers' conjecture still holds or not.

Proposition 4. Suppose that a firm decides to either expand or maintain capacity at the state where the firm is on the verge of bankruptcy in period 2. As the firm sells capital at a higher price in period 2, the firm will then install a larger capacity in period 1, while issuing a smaller amount of bonds if the "debt overhang" problem either remains unchanged or exacerbates.

The intuition behind Proposition 4 is as follows (see the Appendix). Suppose that we both start from an initial equilibrium point $E_{a}$ in Figure 2 and classify a firm's capacity decision in period 2 into three cases as mentioned above. Consider the firm that sells capital at a higher price in period 2. Given the firm's choice of debt levels, its incentive to install capacity in period 1 will be unchanged under cases (i) and (ii) because the value of $\Delta_{14}$ in (A9) is equal to zero. For case (iii), the sign of $\Delta_{14}$ is positive, and thus this incentive will be raised both because the floor below the

marginal return to capital in period 2 becomes higher, and also because by (10), the firm has a larger solvent region in period 2.

Consider cases (i) and (ii). Given the firm's choice of period 1 capacity, the effect of a rise in the resale price of period 2 capital on the firm's incentive to issue bonds is determined by the sign of $\Delta_{24}$ in equation (A10). The last term on the right-hand side of (A10) will be equal to zero, suggesting that the marginal tax shield benefit of debt remains unchanged. The marginal agency cost of financing will be higher if the "debt overhang" problem becomes either more severe or unchanged, i.e., if $\partial\left(d K_{1}^{*} / d B^{*}\right) / \partial b_{l} \leq 0$; this is because on the right-hand side of (A10), the first term will be non-positive, while the second term will be negative because the term $\partial^{2} V_{1 D}\left(K_{1}^{*}(\cdot), B^{*}(\cdot), \cdot\right) / \partial K_{1} \partial b_{l}$ will be positive. In Figure 2, line $Y Y$ that shifts leftward to line $Y^{\prime} Y^{\prime}$ captures this effect. Comparing the new equilibrium point $E_{c}$ for cases (i) and (ii), the intersection of lines $X X$ and $Y^{\prime} Y^{\prime}$, with the initial one, $E_{a}$, yields the result of Proposition 4.

Equations (A11) and (A12) indicate that for all cases other than that stated in Proposition 4, the impacts of changes in the resale price of capital on choices of financial structure and period 1 capacity are both indefinite.

The result of Proposition 4 can be compared with that of Williamson (1985). Williamson conjectures that lower asset specificity will raise debt capacity. In my analysis, lower asset specificity will result in a higher resale price of capital in period 2. Proposition 4 thus delineates a case in which lower asset specificity is associated with a smaller rather than larger debt capacity.

\section{Numerical Analysis}

I demonstrate the results in preceding sections through numerical examples. I assume that the return to period 1 capital $r\left(K_{1}\right)=K_{1}^{\alpha}$, and the return to period 2 capital $R\left(K_{2}, e_{2}\right)=K_{2}^{\alpha} e_{2}$, where

$1>\alpha>0$ and $e_{2}$ is uniformly distributed over the interval $\left[\underline{e}_{2}, \overline{e_{2}}\right]$. The base-case parameter values are as follows: the purchase price of capital in period $1 b=1$, the risk-adjusted discount factor $\theta=0.9$, the corporate tax rate $\tau=0.2$, the purchase price of capital in period $2 b_{h}=1.05$, 
TABLE 1 .

\begin{tabular}{cccccc}
\hline $\begin{array}{c}\text { Exogenous } \\
\text { Variables }\end{array}$ & $B^{*}(\cdot)$ & $K_{1}^{*}(\cdot)$ & $\hat{e}_{2 m}$ & $V_{1}\left(K_{1}^{*}(\cdot), B^{*}(\cdot), \cdot\right)$ & $\frac{V_{1 D}\left(K_{1}^{*}(\cdot), B^{*}(\cdot), \cdot\right)}{V_{1}\left(K_{1}^{*}(\cdot), B^{*}(\cdot), \cdot\right)}$ \\
\cline { 3 - 6 } & & & & & \\
$b_{h}$ & & & & & \\
1.01 & 0.778 & 0.4910 & 1.034 & 0.8656 & 0.612 \\
1.03 & 0.783 & 0.4925 & 1.039 & 0.8660 & 0.614 \\
1.05 & 0.787 & 0.4936 & 1.044 & 0.8665 & 0.616 \\
1.07 & 0.792 & 0.4945 & 1.050 & 0.8669 & 0.618 \\
1.09 & 0.796 & 0.4949 & 1.055 & 0.8673 & 0.620 \\
& & & & & \\
$b_{l}$ & & & & & 0.620 \\
0.10 & 0.806 & 0.4845 & 1.078 & 0.8576 & 0.618 \\
0.20 & 0.799 & 0.4880 & 1.065 & 0.8609 & 0.616 \\
0.30 & 0.788 & 0.4936 & 1.045 & 0.8665 & 0.613 \\
0.40 & 0.771 & 0.5013 & 1.016 & 0.8745 & 0.609 \\
0.50 & 0.748 & 0.5109 & 0.979 & 0.8852 & \\
\hline
\end{tabular}

Note: Choice of debt obligations $B^{*}(\cdot)$, choice of period 1 capacity $K_{1}^{*}(\cdot)$, the level of $e_{2}$ where bankruptcy just occurs $\hat{e}_{2 m}$, total firm value in period $1 V_{1}\left(K_{1}^{*}(\cdot), B^{*}(\cdot),\right)$, and the debt-to-firm value ratio $V_{1 D}\left(K_{1}^{*}(\cdot), B^{*}(\cdot),\right) / V_{1}\left(K_{1}^{*}(\cdot), B^{*}(\cdot), \cdot\right)$; the parameter values for the benchmark case are $b=1, \theta=0.9, \tau=0.2, b_{h}=1.05, b_{l}=0.3, \alpha=0.4, \underline{e}_{2}=0$, and $\overline{e_{2}}=2$.

the resale price of capital $b_{l}=0.3$, the output elasticity of capital $\alpha=0.4, \underline{e}_{2}=0$, and $\bar{e}_{2}=2$. The terms $b, b_{h}$, and $\theta$ are chosen to satisfy the convergence requirement $b>\theta b_{h}$. In addition, the tax rate $\tau$ reflects personal tax advantages to equity returns, which lower the tax advantage of debt to below the corporate rate of 35 percent (Leland, 1998).

With these benchmark parameter values, Table 1 shows that (1) the optimal level of bonds $B^{*}(\cdot)=0.787$, (2) the optimal capacity in period $1 K_{1}^{*}(\cdot)=0.4936$, (3) the level of $e_{2}$ where bankruptcy just occurs $\hat{e}_{2 m}=1.044$; i.e., the probability of bankruptcy in period 2 is 52.2 percent, and the firm decides to neither expand nor contract capacity at the state where the firm is on the verge of bankruptcy in period 2, (4) total firm value $V_{1}\left(K_{1}^{*}(\cdot), B^{*}(\cdot), \cdot\right)=0.8665$, and (5) the debtto-firm value ratio $V_{1 D}\left(K_{1}^{*}(\cdot), B^{*}(\cdot), \cdot\right) / V_{1}\left(K_{1}^{*}(\cdot), B^{*}(\cdot),\right)=0.616$. Table 1 also reports how these five terms respond to changes of both the purchase price of capital in period $2, b_{h}$, over a region [1.01, 1.09], and the resale price of capital in period $2, b_{l}$, over a region [0.1, 0.5], holding all other parameters at their benchmark values. Several results are derived.

First, the total effect of a rise in $b_{h}$ on $B^{*}(\cdot)$ and $K_{1}^{*}(\cdot)$ corresponds to the case stated in Proposition 3. A higher purchase price of capital in period 2 exhibits two effects on $B^{*}(\cdot)$ and 
$K_{1}^{*}(\cdot)$. (1) Given choices of debt levels, the ceiling on the marginal return to period 2 capital becomes higher; and therefore, the incentive to install capital in period 1 becomes higher. A larger capacity in period 1, in turn, raises debt capacity. (2) Given choices of period 1 capacity, the marginal agency cost of debt becomes less severe; and therefore, the incentive to issue bonds becomes higher. A larger debt capacity, in turn, reduces the incentive to install capacity in period 1 by Proposition 2. The total effect of a rise in $b_{h}$ is to raise debt capacity because the first and second effects reinforce each other. Given that a higher $b_{h}$ is associated with a lower growth option value by Proposition 1, my result is thus in line with Myers' conjecture, which states that a firm's debt capacity is inversely related to its growth option value. Furthermore, the total effect of a rise in $b_{h}$ is to raise the incentive to install period 1 capacity because the first effect more than offsets the second one.

Second, the total effect of a rise in $b_{h}$ is to raise $\hat{e}_{2 m}$, i.e., a firm that purchases capital at a higher price in period 2 is more likely to fall into bankruptcy, because two induced effects will arise with the former more than offsetting the latter: (i) $\hat{e}_{2 m}$ becomes higher as a result of a larger debt capacity by (8a); and (ii) $\hat{e}_{2 m}$ becomes lower as a result of a larger capacity in period 1 by (7a).

Third, a higher $b_{h}$ raises $V\left(K_{1}^{*}(\cdot), B^{*}(\cdot), \cdot\right)$, suggesting that a firm that purchases capital at a higher price in period 2 will have larger total firm value in period 1. A higher $b_{h}$ exhibits three effects on total firm value in period 1 with the last two effects more than offsetting the first one: (i) by Proposition 1, given choices of debt obligations and period 1 capacity, the growth option value becomes lower, and therefore, total firm value in period 1 also becomes lower; (ii) choices of period 1 capacity become higher, which results in both larger debt value in period 1 by (18a), and therefore, larger total firm value in period 1; and (iii) choices of debt levels become higher, which results in both larger magnitude of tax savings, and therefore, larger total firm value in period 1.

Fourth, the total effect of a rise in $b_{l}$ on $B^{*}(\cdot)$ and $K_{1}^{*}(\cdot)$ corresponds to the case stated in Proposition 4. Given choices of period 1 capacity, a higher resale price of capital in period 2 raises the marginal agency cost of debt, and therefore, reduces debt capacity. A lower debt capacity, in turn, raises the incentive to install capital in period 1 by Proposition 2. The total effect of a rise in $b_{l}$ is thus to reduce debt capacity and raise period 1 capacity.

Fifth, the total effect of a rise in $b_{l}$ is to reduce $\hat{e}_{2 m}$, i.e., a firm that sells installed capital at a higher price in period 2 will be less likely to fall into bankruptcy because two induced effects will arise with the latter more than offsetting the former: (i) $\hat{e}_{2 m}$ becomes lower as a result of a lower debt capacity; and (ii) $\hat{e}_{2 m}$ becomes lower as a result of a larger period 1 capacity.

Sixth, a firm that sells installed capital at a higher price in period 2 will have larger total firm value in period 1 because a higher $b_{l}$ exhibits three effects on total firm value in period 1 with the first two effects more than offsetting the last one: (i) by footnote 7, given choices of debt obligations and period 1 capacity, the put option value becomes higher, and therefore, total firm value in period 1 also becomes higher; (ii) choices of period 1 capacity become higher, which results in both larger debt value in period 1, and therefore, larger total firm value in period 1; (iii) choices of debt levels become lower, which results in both smaller magnitude of tax savings, and therefore, lower total firm value in period 1.

Finally, both a higher $b_{h}$ and a lower $b_{l}$ are associated with a higher debt-to-firm value ratio. In other words, debtholders will receive more benefits than equityholders from either purchasing capital at a higher price or selling installed capital at a lower price in period 2. 


\section{Conclusion}

The seminal paper by Modigliani and Miller (1958) states that a firm's financing decision is distinct from its investment decision under perfect market assumptions. In this article, these two decisions are linked through three sources of market imperfections. First, capital both has some resale value and is more costly to later purchase. Second, debt obligations are tax deductible with full loss offsets. Finally, a conflict of interest between equity and debt holders arises because equity has limited liability.

In this article, a firm's existing debt load causes it to install a smaller initial capacity; i.e., the "debt overhang" problem arises. This leads to lower debt value. However, such a cost should be borne by equityholders because the firm and its creditors will rationally expect equityholders' future behavior. Consequently, debt financing involves a tradeoff between this agency cost and the tax shield benefit of debt. Abel et al. (1996) show that for an all-equity financed firm, its incentive to install initial capacity will be higher as the firm incurs higher costs to later purchase capital in the later period. This effect may be either more than, exactly, or less than offset by the induced effect of debt financing. This, in turn, induces an ambiguous effect on the firm's choice of debt levels. Consequently, a lower growth option value, which results from paying more costs to purchase capital in the later period, will exhibit an ambiguous relationship with the choice of debt levels. However, the simulation results of this article are in line with Myers' conjecture (1977), which predicts an inverse relationship between them.

Future research may be extended in two ways. First, those variables that affect growth option values such as competition (Brander and Lewis, 1986) and uncertainty can be included. Second, one may collect data on variable that capture limited expandability $\left(b_{h}\right)$ and leverage to test the Myers conjecture. The result can then be compared with that of previous study, which uses either $\mathrm{R} \& \mathrm{D}$ intensity or the ratio of a firm's market value to its book value as a proxy for growth option values.

\section{References}

Abel, A. B., A. K. Dixit, J. C. Eberly, and R. S. Pindyck. 1996. "Options, the Value of Capital, and Investment." Quarterly Journal of Economics 111: 753-777.

Altman, E. I. 1984. “An Empirical Investigation of the Bankruptcy Cost Question.” Journal of Finance 39: 1067-1089.

Bradley, M., G. Jarrell, and E. Han Kim. 1984. "On the Existence of an Optimal Capital Structure: Theory and Evidence.” Journal of Finance 39: 857-878.

Brander, J. A., and T. R. Lewis. 1986. "Oligopoly and Financial Structure: The Limited Liability Effect.” American Economic Review 76: 956-970.

Dixit, A. K., and R. S. Pindyck. 1994. Investment under Uncertainty. Princeton: Princeton University Press.

Fries, S., M. Miller, and W. Perraudin. 1997. "Debt in Industry Equilibrium.” Review of Financial Studies 10: 39-67.

Gaver, J. J., and K. M. Gaver. 1993. "Additional Evidence on the Association Between the Investment Opportunity Set and Corporate Financing, Dividend and Compensation Policies." Journal of Accounting and Economics 16: 125-160.

Harris, M., and A. Raviv. 1991. “The theory of capital structure.” Journal of Finance 46: 297-355.

Haugen R., and L. W. Senbet. 1978. "The Insignificance of Bankruptcy Costs to the Theory of Optimal Capital Structure.” Journal of Finance 33: 383-393. 
Jou, J-B. 2001. "Entry, Bankruptcy, and Financing Decisions: The Limited Liability Effect." Quarterly Review of Economics and Finance 41: 69-88.

Mauer, D. C., and S. H. Ott. 2000. "Agency Costs, Investment Policy and Optimal Capital Structure: The Effect of Growth Options." In Project Flexibility, Agency, and Product Market Competition, pp. 151-180, edited by M. J. Brennan and L. Trigeorgis. London: Oxford University Press.

Mello, A. S., and J. E. Parsons. 1992. "The Agency Costs of Debt." Journal of Finance 47: 18871904.

Mello, A. S., J. E. Parsons, and A. J. Triantis. 1995. "An Integrated Model of Multinational Flexibility and Financial Hedging." Journal of International Economics 39: 27-51.

Modigliani, F., and M. H. Miller. 1958. "The cost of capital, corporation finance, and the theory of investment." American Economic Review 48: 261-297.

Myers, S. C. 1977. "Determinants of corporate borrowing." Journal of Financial Economics 4: 147-176.

Smith, C., and R. Watts. 1992. "The Investment Opportunity Set and Corporate Financing, Dividend, and Compensation Policies." Journal of Financial Economics 32: 263-292.

Titman, S., and R. Wessels. 1988. "The Determinants of Capital Structure Choice." Journal of Finance 43: 1-19.

Tobin, J. 1969. “A General Equilibrium Approach to Monetary Theory.” Journal of Money, Credit, and Banking 1: 15-29.

Warner, J. B. 1977. “Bankruptcy Costs: Some Evidence.” Journal of Finance 32: 337-348.

Williamson, O. E. 1985. The Economic Institutions of Capitalism. New York: The Free Press.

\section{Appendix}

\section{Proof of Proposition 3}

Totally differentiating (14') and (22') with respect to $b_{h}$ yields

$$
\begin{aligned}
& \Delta_{11} \frac{d K_{1}^{*}(\cdot)}{d b_{h}}+\Delta_{12} \frac{d B^{*}(\cdot)}{d b_{h}}+\Delta_{13}=0, \\
& \Delta_{21} \frac{d K_{1}^{*}(\cdot)}{d b_{h}}+\Delta_{22} \frac{d B^{*}(\cdot)}{d b_{h}}+\Delta_{23}=0,
\end{aligned}
$$

where $\Delta_{11}<0$ is given by $\left(16 b^{\prime}\right), \Delta_{12}<0$ is given by $\left(16 \mathrm{c}^{\prime}\right), \Delta_{21}>0$ is given by (23b), and $\Delta_{22}<0$ is given by (23c),

$$
\begin{aligned}
& \Delta_{13}=\frac{\partial^{2} V_{1 E}\left(K_{1}^{*}(\cdot), B^{*}(\cdot),\right)}{\partial K_{1} \partial b_{h}} \frac{\geq 0}{<} \\
& \Delta_{23}=\frac{\partial V_{1 D}\left(K_{1}^{*}(\cdot), B^{*}(\cdot),\right)}{\partial K_{1}} \frac{\partial\left(d K_{1}^{*} / d B^{*}\right)}{\partial b_{h}}+\frac{\partial^{2} V_{1 D}\left(K_{1}^{*}(\cdot), B^{*}(\cdot),\right)}{\partial K_{1} \partial b_{h}} \frac{d K_{1}^{*}(\cdot)}{d B^{*}}+\frac{\partial^{2} V_{1}\left(K_{1}^{*}(\cdot), B^{*}(\cdot),\right)}{\partial B \partial b_{h}} \frac{\geq 0 .}{<} 0 . \\
& (+) \quad\left(\frac{\geq}{<} 0\right) \\
& (\geq 0) \\
& (-) \\
& (\leq 0)
\end{aligned}
$$

Solving (A1) and (A2) simultaneously yields 


$$
\begin{aligned}
& \frac{d K_{1}^{*}(\cdot)}{d b_{h}}=\frac{-\Delta_{13} \Delta_{22}}{\Delta_{11} \Delta_{22}-\Delta_{12} \Delta_{21}}+\frac{\Delta_{12} \Delta_{23}}{\Delta_{11} \Delta_{22}-\Delta_{12} \Delta_{21}} \geq 0, \\
& \frac{d B^{*}(\cdot)}{d b_{h}}=\frac{-\Delta_{11} \Delta_{23}}{\Delta_{11} \Delta_{22}-\Delta_{12} \Delta_{21}}+\frac{\Delta_{13} \Delta_{21}}{\Delta_{11} \Delta_{22}-\Delta_{12} \Delta_{21}} \geq 0 .
\end{aligned}
$$

\section{Proof of Proposition 4}

Totally differentiating (14') and (22') with respect to $b_{l}$ yields

$$
\begin{aligned}
& \Delta_{11} \frac{d K_{1}^{*}(\cdot)}{d b_{l}}+\Delta_{12} \frac{d B^{*}(\cdot)}{d b_{l}}+\Delta_{14}=0, \\
& \Delta_{21} \frac{d K_{1}^{*}(\cdot)}{d b_{l}}+\Delta_{22} \frac{d B^{*}(\cdot)}{d b_{l}}+\Delta_{24}=0,
\end{aligned}
$$

where

$$
\begin{aligned}
& \Delta_{14}=\frac{\partial^{2} V_{1 E}\left(K_{1}^{*}(\cdot), B^{*}(\cdot),\right)}{\partial K_{1} \partial b_{l}} \geq 0, \\
& \Delta_{24}=\frac{\partial V_{1 D}\left(K_{1}^{*}(\cdot), B^{*}(\cdot), \cdot\right)}{\partial K_{1}} \frac{\partial\left(d K_{1}^{*} / d B^{*}\right)}{\partial b_{l}}+\frac{\partial^{2} V_{1 D}\left(K_{1}^{*}(\cdot), B^{*}(\cdot) \cdot\right)}{\partial K_{1} \partial b_{l}} \frac{d K_{1}^{*}}{d B^{*}}+\frac{\partial^{2} V_{1}\left(K_{1}^{*}(\cdot), B^{*}(\cdot),\right)}{\partial B \partial b_{1}} \underset{<}{<} 0 .
\end{aligned}
$$

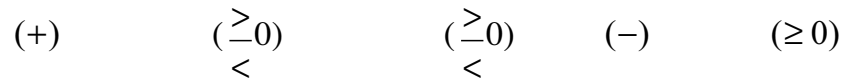

Solving (A7) and (A8) simultaneously yields

$$
\begin{aligned}
& \frac{d K_{1}^{*}(\cdot)}{d b_{l}}=\frac{-\Delta_{14} \Delta_{22}}{\Delta_{11} \Delta_{22}-\Delta_{12} \Delta_{21}}+\frac{\Delta_{12} \Delta_{24}}{\Delta_{11} \Delta_{22}-\Delta_{12} \Delta_{21}} \geq 0, \\
& \frac{d B^{*}(\cdot)}{d b_{l}}=\frac{-\Delta_{11} \Delta_{24}}{\Delta_{11} \Delta_{22}-\Delta_{12} \Delta_{21}}+\frac{\Delta_{14} \Delta_{21}}{\Delta_{11} \Delta_{22}-\Delta_{12} \Delta_{21}} \geq 0 .
\end{aligned}
$$

